\title{
LANGUAGE POLITENESS IN THE JAVANESE VERB SPEECH LEVEL
}

\author{
Dwi Atmawati* \\ Balai Bahasa Daerah Istimewa Yogyakarta \\ Jl. I Dewa Nyoman Oka 34, Yogyakarta 55224, Indonesia \\ atmawatibby@gmail.com
}

Received: $04^{\text {th }}$ March 2021/Revised: $29^{\text {th }}$ April 2021/Accepted: 04 $4^{\text {th }}$ May 2021

How to Cite: Atmawati, D. (2021). Language politeness in the Javanese verb speech level. Lingua Cultura, 15(1), 51-57. https://doi.org/10.21512/lc.v15i1.7109

\begin{abstract}
The research aimed to observe the use of Javanese verb forms using a sociolinguistic approach. The object of the research was the selection of Javanese verb forms used by speakers in the Magelang region. The informants were children, adolescents, and adults, both male and female. The informants were 50 Javanese speakers. Data were obtained by the technique of listening, recording, and taking notes. The problem was studied using speech component theory and language politeness norms. The research applied a qualitative descriptive method. The result indicates that some children and the younger generation are less able to choose the correct form of verbs related to the level of speech, for example, the words 'siram' (bath), 'tindak' (go), and 'mireng'(hear). These three words should refer to people with whom to speak and be respected, not to describe oneself. Using an inaccurate form of the verbs can lead to an assumption that the speaker is impolite. Based on the findings of the research, it is hoped that there will be efforts, both in the domain of families, schools, stakeholders, and policymakers, to provide better education to speakers, especially children, and the younger generation. With better education, it is hoped that the younger generation will be able to understand well the proper use of verbs. Incorrect use of the verb form can indicate the impoliteness of the speaker.
\end{abstract}

Keywords: language politeness, Javanese verbs, speech level

\section{INTRODUCTION}

Magelang is a city and regency located in Central Java, Indonesia. Mother tongue of the people of Magelang is Javanese. However, in its development, some Magelang people are no longer use Javanese as a means of daily communication. Some speakers have switched to using Indonesian as a means of communication. The use of Indonesian as a means of daily communication by some Javanese has indirectly shifted the role of Javanese. The Javanese language, which was originally used, among other things, to communicate between Javanese people, has been displaced by the Indonesian language. This shift cannot be separated from the role of some parents who are no longer inherit Javanese as a mother tongue to their children.

This has resulted in the emergence of a generation that cannot speak Javanese well. The inability to speak Javanese in children or the younger generation can be seen when they communicate in Javanese. Some of them do not understand the correct use of Javanese verb speech levels. An example is the use of the verbs ngoko and krama. They can only or know ngoko Javanese and are not or less able to use krama Javanese. In fact, there is a very clear speech level in Javanese society, namely ngoko Javanese and Javanese manners. The use of Javanese ngoko and Javanese krama is closely related to language politeness. The inability of a speaker to speak Javanese can lead to the assumption that these speakers are not polite. Politeness or impoliteness can be expressed in the choice of words, both verbs and nouns.

Research on errors in the use of Javanese verbs has never been done. The research is important to determine the extent to which language impoliteness has occurred in the use of Javanese verbs. After it is known that language impoliteness is associated with choosing the incorrect verb form, the research can explain the correct Javanese verb form. By explaining the use of the proper Javanese verb form, it is hoped that readers will be able to understand and apply it. Cahyadi (2018) has found that Javanese language subjects are difficult to develop because students are less able to speak 
Javanese correctly. Learning Javanese is important so that everyone can be polite when speaking. It is hoped that the results of the research can be used by parents, educators, and the community to provide an example in choosing the correct verb form. It is important to know the results of the research widely so that parents, communities, stakeholders, and policymakers can take steps to teach politeness in Javanese. Through these steps, it is hoped that children and adolescents can speak more politely because they can choose and use verbs appropriately. For stakeholders, the results of the research are expected to be used as a reference in policymaking. Choosing the correct verb form shows that the speaker is polite.

Some researches carried out related to the research are the research on speech level phenomena and research on gender and politeness. Romelah (2016) has stated that the forms of chaos in the speech level that occurred in Puring district, Kebumen, include the form of krama inggil to ngoko alus, the form of ngoko alus to krama inggil, and the form of ngoko to krama inggil to polite manners. Furthermore, research on the choice of Javanese speech level in Klapaduwur village, Blora. In daily communication, people in Klapadhuwur village usually use the ngoko language, including communication between husband and wife, and children to parents. Although for some Javanese people in other areas, this is considered impolite (Trahutami, 2016).

Research conducted by Nuryantiningsih and Pandanwangi (2018) regarding politeness and impoliteness in Javanese society is still limited to studies from a pragmatic point of view with the speech act theory. Saputri, Sariono, and Rochiyati (2018) have stated that the use of Javanese speech levels by the Madurese ethnic community is influenced by setting, scene, and participant. Research on the use of Javanese speech levels by the Madurese ethnic community is focused on discussing the factors that influence the level of speech.

Changes in social status in students do not affect politeness in language. The students continue to speak politely even though their social status has improved (Rahmi, 2018). InTegaldistrict, standard Indonesianand Javanese are included in the high variety of languages used in formal situations, and non-standard Indonesian and Javanese are used in informal situations and are included in the low language variation (Saddiyah \& Rokhman 2018). Winarti (2018) has stated that the threat to krama as a legacy of the Indonesian language may be extinct. Krauße (2018) has stated that among Surabaya's young speakers, polite vocabulary is rarely used. Some people are afraid to speak in their mother tongue because the classical speech level system is still dominant. They choose to speak Indonesian that does not have a speech level.

Furthermore, the research reveals the categories and language expressions in coastal Javanese communities Banjar Kemuning village, Sidoarjo regency based on the perspective of ethnolinguistic studies (Chafidhi, Rais, \& Dwi, 2019). The relativity of language and culture is a sporadic cultural value that is often expressed at the lexical level. If the relativity of language and culture is brought to the domain of teaching a second language or a foreign language, it is possible to misunderstand the communication and the learning process (Kholik, Ridwan, \& Hadi, 2019). In most Javanese families, children talk to their parents in a polite manner (Sugianto \& Salehuddin, 2019). Some of the younger generation with Javanese parents use Indonesian as their mother tongue. The younger generation has a stronger sense of national identity than a sense of local identity. To increase the vitality of the Javanese language as a local identity, intergenerational transmission and use of Javanese in schools are required (Andriyanti, 2019). Furthermore, the research on Javanese nonverbal language uses an ethnopragmatic approach. If the local wisdom of Javanese people in the nonverbal language is preserved, it will be beneficial for future generations (Pranowo, 2019). Wahyuningsih (2019) has stated that the use of Indonesian for male lecturers and male staff at IAIN Kudus experience a less pronounced shift than the language shift in women. Lecturers and female employees tend to have a strong preference for Indonesian over Javanese.

Other researchers have revealed that the use of Javanese krama by the younger generation in Jebres, Banjarsari, Pasar Kliwon, and Surakarta districts tends to occur in code-switching, mixing codes with Indonesian, and the inaccuracy of Javanese lexicons (Sujono, Padmaningsih, \& Supardjo, 2019). Javanese ngoko language used in Paciran, Lamongan, East Java, Indonesia is in a stable position while Javanese krama is at risk of being endangered. In Paciran village, there is a shift from krama to ngoko (Klok, 2019). Children of Javanese parents who live in Pulo Loih village, Pidie, Aceh are no longer use Javanese to communicate even though their parents still use Javanese to interact with others their age. Parents are no longer teach Javanese to their children due to economic, security, and social factors. This has caused a shift in the Javanese language (Zulfikar, Aziz, \& Muthalib, 2020). The research is limited to the study of the Javanese language shift. The next researcher has stated that the Javanese people in the Bandar Medan area still pay attention to the ethics of Javanese language politeness (Pohan, 2020).

There is a difference between the research and previous research. In previous research, the Javanese language tends to be studied structurally, morphologically, semantically, ethnolinguistic, and anthropolinguistics. In the research, the selection and use of Javanese verb forms are from a sociolinguistic perspective. The problem is the inability of children and young people to choose Javanese verbs correctly. The verb that is meant here is a verb that is related to the level of speech. The scope of the research is limited to the use of verb speech levels in Javanese. The problem is studied from a sociolinguistic point of view, and it aims to explain the use of verb speech levels in Javanese. 


\section{METHODS}

The research applies a qualitative descriptive method. The stages taken are data acquisition, data analysis, and presentation of the results of data analysis. The data are obtained by using the listening proficiently and the free listening technique (Sudaryanto, 2015).

Data collection is done by listening to, taking notes, recording conversations in the family domain and public places, for example, on the street, in the market in the Magelang region. The selected informants are children, young people, and adults, both men and women, as many as 50 people. The researcher records conversations between children and parents in the family domain. When in a public place, they know that a conversation is data, therefore the researcher records it. Furthermore, data analysis is carried out through the identification, classification, and interpretation stages. The validity of the data is measured by semantic validity, and it also matches with relevant theories. Reliability is obtained by making careful and continuous observations. That is, the researcher gets the same data repeatedly with different informants. When data about the inaccuracy of Javanese verbs is obtained repeatedly, it shows that the data is valid. The data are analyzed using the speech level theory of Poedjosoedarmo (1968) and the speech component theory of Hymes (1974) for the study of problems from a sociolinguistic point of view. In this analysis, study the extralingual factors that influence the choice of Javanese verb forms. In addition, data analysis is carried out by studying intralingual factors. Hymes (1974) has said that extralingual aspects include who is involved in the dialogue, how the relationship and social distance between them, the setting of the speech event, the goals to be achieved, the media used, and how to express them.

Intralingual factors are the elements of language that make up meaning. Extralingual factors are factors outside of language that support the intent of the author or speaker. Extralingual factors can take the form of context. In spoken language, extralingual factors can be gestures or expressions (Pranowo, 2015).

\section{RESULTS AND DISCUSSIONS}

The research discusses the use of incorrect Javanese verb forms. Inaccurate use of the verb form of the language can lead to the assumption of language impoliteness. The problems are discussed by referring to the speech level theory from Poedjosoedarmo (1968). He has stated that speech levels in Javanese constitute a system for showing (1) the degree of formality, and (2) the degree of respect felt by the speaker toward the addressee. The vocabulary at the Javanese speech level includes ngoko, madya, and krama. Ngoko is a form of speech that is disrespectful or informal; madya is semi-polite and semi-formal speech; and krama is a polite and formal form of speech (Poedjosoedarmo, 1968).
Hymes (1974) has used the word SPEAKING as an acronym to explain his theory about the components of speech. Setting and scene (S) refer to the time and place of the speech event. Participant (P) consists of various speaker-listener, address or addressee, or sender-receiver combination. Ends (E) refer to the goals to be achieved from the speech. Act (A) refers to events where a speaker is taking the opportunity to speak. Key $(\mathrm{K})$ refers to the tone of voice, the variety of language used, and the manner of expressing opinions. Instrumentalities (I) refer to a tool for expressing an opinion, such as verbally, in writing, by telephone, etc. Norms of interaction and interpretation $(\mathrm{N})$ refer to the rules that must be obeyed by the speech participants. Finally, genre $(G)$ refers to a type of speech that is clearly defined, for example, poetry, sermons, prayers, and others (Hymes, 1974).

The Javanese language has a fairly complex speech level. Broadly speaking, the level of speech in Javanese consists of ngoko, madya, and krama. Javanese ngoko is usually used by Javanese speakers to communicate with other speakers who are familiar, have younger age, or have lower social status. Javanese madya is usually used by speakers to communicate with people who are not yet known or have unfamiliar relationships. The Javanese krama language is usually used by speakers to communicate with other speakers who are respected, are older, or have higher social status. The choice or use of speech levels is closely related to language politeness. Poedjosoedarmo (2017) has stated that politeness in Javanese includes friendly, patient, respectful, clear, and concise speech. Table 1 shows the data, classification, and discussion of verb forms in Javanese in the research. The data are classified based on the speech level in Javanese, namely ngoko, madya, and krama, which are limited to the form of verbs.

Table 1 Classification of Verb Forms in Javanese

\begin{tabular}{llll}
\hline $\begin{array}{c}\text { Ngoko (Ng) } \\
\text { Javanese }\end{array}$ & $\begin{array}{c}\text { Madya (Md) } \\
\text { Javanese }\end{array}$ & $\begin{array}{l}\text { Krama (Kr) } \\
\text { Javanese }\end{array}$ & English \\
\hline adus & - & siram & bath \\
krungu & - & mireng & hear \\
lunga & kesah & tindak & go \\
lungguh & - & lenggah & seat \\
maca & - & maos & read \\
mbadhog, & nedha & dhahar & eat \\
nguntal, & & & \\
mangan, & & & \\
madhang & & mbetahaken & need \\
mbutuhke & mbetahke & nyaosi, & give \\
menehi & maringi & ngaturi & \\
& & sare & sleep \\
micek, turu & tilem & tindak & walk \\
mlaku & mlampah & mrisani & look \\
ndelok & ningali & & \\
\hline
\end{tabular}


Table 1 Classification of Verb Forms in Javanese (Continued)

\begin{tabular}{llll}
\hline $\begin{array}{c}\text { Ngoko (Ng) } \\
\text { Javanese }\end{array}$ & $\begin{array}{l}\text { Madya (Md) } \\
\text { Javanese }\end{array}$ & $\begin{array}{l}\text { Krama (Kr) } \\
\text { Javanese }\end{array}$ & English \\
\hline nganggo & ngangge & ngagem & use \\
nggawa & mbeta & ngasta & bring \\
nggawe & - & ndamel & make \\
ngokop, & - & ngunjuk & drink \\
ngombe & & ngendika & say \\
ngomong & mungel & nyuwun & ask \\
njaluk & - & ndukani & angry \\
nyeneni & - & wungu & wake up \\
tangi & - & rawuh & come \\
teka & dumugi & mundhut & buy \\
tuku & tumbas & & \\
\hline
\end{tabular}

In the research, it is found data on the use of Javanese verbs, namely adus (Ng), siram (Kr); krungu $(\mathrm{Ng})$, mireng (Kr); lunga (ng), kesah (Md), tindak $(\mathrm{Kr})$; lungguh (Ng), lenggah (Kr); maca (Ng), maos (Kr); mbadhog, nguntal, mangan, madhang(Ng), nedha (Md), dhahar (Kr); mbutuhke (Ng), mbetahke $(\mathrm{Md})$, mbetahaken $(\mathrm{Kr})$; menehi $(\mathrm{Ng})$, maringi $(\mathrm{Md})$, nyaosi, ngaturi (Kr); micek, turu (Ng), tilem (Md), sare (Kr); mlaku (Ng), mlampah (Md), tindak (Kr); ndelok $(\mathrm{Ng})$, ningali $(\mathrm{Md})$, mrisani $(\mathrm{Kr})$; nganggo $(\mathrm{Ng})$, ngangge (Md), ngagem (Kr); nggawa (Ng), mbeta (Md), ngasta (Kr); nggawe (Ng), ndamel (Kr); ngokop, ngombe (Ng), ngunjuk (Kr); ngomong ( $\mathrm{Ng})$, mungel (Md), ngendika (Kr); njaluk (Ng), nyuwun $(\mathrm{Kr})$; nyeneni $(\mathrm{Ng})$, ndukani (Kr); tangi $(\mathrm{Ng})$, wungu (Kr); teka (Ng), dumugi (Md), rawuh (Kr); tuku (Ng), tumbas (Md), mundhut (Kr). Based on these data, it is known that there are verbs that have the form ngoko and krama but do not have madya forms, for example, adus, krungu, langat, maca, nggawe, ngombe, njaluk, nyeneni, tangi. When the madya form of the verb does not exist in Javanese, speakers will use the verb krama when talking to strangers, older people, people of higher social status, or respected people.

However, in reality, relatively many speakers cannot speak Javanese well. They are not precise in choosing or using verbs. The inaccuracy of using Javanese verbs is revealed in the dialogue (1). In this research, data on the form of Javanese verbs used by speakers are not correct. Dialogue (1) shows some data and discussion.

(1) Verb of siram (bath)

A: "Apa kowe wis adus?" "Have you taken a bath?"

B: "Badhe ajeng siram." "I was just going to take a shower."

The speech in Dialogue (1) is in the family domain. A is B's father. A uses Javanese ngoko to B. This is in accordance with the norms of language in Javanese society; namely, parents have a higher position, and sons have an obligation to respect their parents. B as a son uses Javanese with a higher level of speech, namely manners. The purpose of using Javanese manners is to respect their parents. However, $\mathrm{B}$ chooses the form of the verb flushes not quite right. The choice of the verb siram is due to B not understanding the difference in using the verb siram. In the norms of language politeness, the verb siram, a form of manners, is used for respected others, not for themselves, for example, Bapak sampun siram (Dad has taken a shower). The verb for itself is used adus (bath), for example, Kula sampun adus (I have taken a bath).

(2) Verb of mireng (hear)

C: "Kowe wis krungu kabar kui?" "Have you heard the news?"

D: "Sampun. Kula sampun mireng wingi." "I did. I heard yesterday."

Dialogue (2) is in the family domain. C is D's mother. In Javanese society, the mother as a parent has a high position that must be respected by the child. In the dialogue, $\mathrm{C}$ uses ngoko Javanese, while D uses krama Javanese. The choice of mireng verb form is incorrect. Mireng verbs are appropriate for people who are respected, not for self-talk. The inaccuracy in the use of mireng verbs is caused by the lack of understanding of $\mathrm{D}$ towards the difference in using the words krungu and mireng. In fact, D means to respect $\mathrm{C}$ by choosing mireng, which is a form of krama verbs. $\mathrm{C}$ wants to show politeness in language. However, because $\mathrm{D}$ chose the wrong form of the verb, there is an assumption that $\mathrm{D}$ is not polite.

\section{(3) Verb of tindak (go)}
E: "Badhe tindak pundi?" "Where are you going?"
F: "Tindak peken." "To the market."

Dialogue (3) takes place on the street when E meets F. The two speakers already know and are of the same age but not very familiar. They use speech levels to communicate. E chooses the tindak verb addressed to $\mathrm{F}$ in his honor. $\mathrm{F}$ also uses the speech level to honor E. However, E uses an incorrect verb, which is a tindak for itself. Supposedly, F chooses the verb dhateng that it shows that $\mathrm{F}$ respects himself. The verb ngoko lunga has kesah madya verb form and tindak krama verb form. In this communication, the verb ngoko lunga is not used because the speaker does not have a close relationship.

\section{(4) Verb of dhahar (eat)}

G: "Ibu, menawi badhe dhahar, sedaya sampun mateng." "Mother, please eat, everything is ready." 
$\mathrm{H}$ : “Ayo, mangan bareng-bareng wae!” "Let's just eat together now!"

G: "Kula mangkih mawon dhahare" "I will eat it later."

Dialogue (4) takes place in the family domain. $H$ is the mother of G. G uses Javanese manners when communicating with his mother. $\mathrm{H}$ answers G's question in ngoko Javanese. G uses krama Javanese for politeness. $\mathrm{H}$ chooses the verb mangan, which is a verb ngoko because $\mathrm{H}$ is talking to her son. $\mathrm{G}$ chooses the verb dhahar, both for his mother and for himself. The use of the verb dhahar for oneself is not correct. In Magelang and its surroundings, the verb dhahar is intended for respected people, not for oneself. $G$ should have chosen the verb nedha. The verb nedha is an madya level of Javanese. Verba eat has a variety of ngoko forms, mbadhog, nguntal, mangan, madhang. The verba mbadhog and nguntal are impolite word. In speaking theory, Hymes (1974) has suggested that speakers should understand politeness in language by paying attention to who, when, social status, situation, where, and the goals of speech.

\section{(5) Verb of sare (sleep)}

I: "Kulanuwun, menapa Pak Toha ada di rumah?" "Excuse me, is $\mathrm{Mr}$ Toha at home?"

J: “Ada, tapi Pak Toha saweg tilem" "Yes, but Mr. Toha is sleeping."

I "Menawi Pak Toha saweg sare, kula titip buku niki." "If Mr. Toha is sleeping, I will leave this book."

Dialogue (5) is in the family domain. Communication is carried out by guests and household assistants. I, as a guest, chooses to use the verb sare, which is addressed to their master, while the household assistant uses the verb tilem. The choice of the tilem verb is not quite right because the speech is addressed to someone who is respected. The sleeping verb has variations in the form of ngoko turu and micek. The verb micek is a crude verb form.

(6) Verb of mrisani (look)

K: "Mangga diprisani. Kainipun sae lan alus." "Please have a look. The fabric is nice and smooth."

L: "Kula prisani riyin kainnya?" "Let me see the fabric."

Dialogue (6) takes place in the market between the seller and the buyer. In buying and selling, the buyer's position is usually higher than the seller. Therefore, there is the expression 'the buyer is king'. $\mathrm{K}$ is a seller, and $\mathrm{L}$ is a buyer. $\mathrm{K}$ chooses the verb diprisani to honor the buyer. L chooses the verb prisani, but it refers to itself. The verb chosen by $\mathrm{L}$ is not correct. Supposedly, L uses the verb ningali that is a madya-level verb.

(7) Verb of ngasta (bring)

M: "Ngasta menapa, ketingalipun awrat sanget." "What did you bring? looks like a lot."

$\mathrm{N}$ : "Mboten ngasta napa-napa, namung oleholeh sekedhik." "I didn't bring anything, just a few gifts."

In Dialogue (7), two friends have a dialogue at home. $\mathrm{M}$ and $\mathrm{N}$ both use the ngasta verb. $\mathrm{M}$ uses the verb ngasta to honor $\mathrm{N}$, while $\mathrm{M}$ uses the verb ngasta to honor itself. In Javanese society, the use of verbs that are meant to honor oneself is considered impolite. $\mathrm{N}$ should have chosen the form of mbeta, not ngasta.

\section{(8) Verb of ngunjuk (drink)}

$\mathrm{O}$ : "Mangga ngunjuk rumiyin." "Please have a drink."

P: "Matur nuwun, kula nembe mawon ngunjuk." "Thank you. I just had a drink."

Dialogue (8) occurs in the family domain. O as the host asks his guests to drink. $\mathrm{O}$ and $\mathrm{P}$ choose the Javanese verb krama, namely ngunjuk. O chooses the verb correctly because the verb ngunjuk is used to refer to guests $\mathrm{P}$. Meanwhile, $\mathrm{P}$ uses the verb ngunjuk inappropriately because it refers to itself. $\mathrm{P}$ should have used the Javanese verb ngoko, ngombe. In ngoko Javanese, there are verbs ngombe and ngokop. The verb ngokop is a low level of speech.

\section{(9) Verb of rawuh (come)}

Q: "Tamunipun sampun dumugi, Bu." "The guest has arrived, Madam."

R: "Diaturi ngenteni sedhela yen tamune wis rawuh." "Say wait a moment when the guest has arrived."

Dialogue (9) takes place at the office. Q, the staff member, tells his boss that his guest has arrived. Q chooses the verb dumugi to refer to the arrival of guests, while $\mathrm{R}$ chooses the verb rawuh. The difference in the choice of verbs is caused by the lack of understanding of Q towards the norms of Javanese politeness. Q does not choose the verb teka because she knows that it is a ngoko verb, which is inappropriate for communicating with the boss.

\section{(10) Verb of mundhut (buy)}

S: "Mangga dipun pundhuti, daging seger!" "Please buy fresh meat."

T: "Pinten regine?" "How much it costs?"

S: "Satus ewu mawon, ajeng mundhut pinten?" "One hundred thousand, how much will you buy?" 
T: "Kula mundhut kalih atus ewu." "I bought two hundred thousand."

Dialogue (10) takes place in the traditional market. $\mathrm{S}$ as a seller offers fresh meat to a buyer, $\mathrm{T}$. He asks the price of fresh meat. $\mathrm{S}$ chooses the passive verb dipundhuti for politeness. Passive verb dipundhuti is Javanese high-level manners. $\mathrm{S}$ does not use the passive verb ditumbasi because it is a madyo level speech. The use of the verb mundhut by T is not correct because the verb mundhut refers to T. T should not show respect for herself. $\mathrm{T}$ should have used the madyo level speech, tumbas.

Based on these data, it is known that some speakers have implemented norms of politeness in language. They pay attention to who is talking to, when, where, and the social status of the addressee to choose the speech level to be used. However, some speakers do not understand the speech level in Javanese, so they cannot use it correctly.

\section{CONCLUSIONS}

Based on these discussions, it is known that there is an inaccuracy in the use of verbs by some speakers, especially the younger generation. This inaccuracy is caused by the speaker's lack of understanding of the Javanese speech level. Inaccurate use of these verbs can lead to the assumption that the speaker is not polite. Therefore, every speaker needs to understand the speech level in Javanese. Solving this problem requires intervention from various parties, such as parents, educators, stakeholders, and policymakers, because a generation who can speak Javanese is necessary. Thus, Javanese language and culture can always be maintained, and language is also a picture of human culture.

The Javanese language has a speech level of ngoko, madyo, and krama. Not every verb is presented at all of these speech levels. Verbs that are always there are at the ngoko and krama levels. There are verbs that are not found at the madyo level. If the verb is not found at the madyo level, the speaker uses a krama level speech.

The next research can study the characteristics of verbs at the madya level of speech; why are the verbs that only have ngoko and krama forms but do not have madya forms. In addition, the research can also conduct studies on how Javanese can be studied interestingly so that children and young people enjoy speaking Javanese. This is interesting to learn because there are lexicons that can express something quite completely in Javanese.

\section{REFERENCES}

Andriyanti, E. (2019). Language shift among Javanese youth and their perception of local and national identities. GEMA Online Journal of Language Studies, 19(3),
109-125. http://dx.doi.org/10.17576/gema-20191903-07.

Cahyadi, R. (2018). Pembelajaran bahasa Jawa dalam membentuk kesantunan berbahasa di MI Muhammadiyah Arenan kecamatan Kaligondang kabupaten Purbalingga. Thesis. Purwokerto: Institut Agama Islam Negeri Purwokerto. Retrieved from http://repository.iainpurwokerto.ac.id/id/ eprint/4277.

Chafidhi, U., Rais, W. A., \& Dwi, P. (2019). Verbal and non-verbal expression in Javanese language of the coastal community in Banjar Kemuning village, Sidoarjo. International Journal of Multicultural and Multireligious Understanding, 6(6), 185-194. http:// dx.doi.org/10.18415/ijmmu.v6i6.1199.

Hymes, D. (1974). Foundation in sociolinguistics: An ethnographic approach. Philadelphia: University of Pensylvania Press.

Kholik, K., Ridwan, M., \& Hadi, S. (2019). Java language in the Madurese cross culture. ISLLAC: Journal of Intensive Studies on Language, Literature, Art, and Culture, 3(2), 190-200.

Klok, J. V. (2019). The Javanese language at risk? Perspectives from an East Java village. Language Documentation \& Conservation, 13, 300-345.

Krauße, D. (2018). Polite vocabulary in the Javanese language of Surabaya. Wacana, 19(1), 58-99. https:// doi.org/10.17510/wacana.v19i1.615.

Nuryantiningsih, F., \& Pandanwangi, W. D. (2018). Politeness and impoliteness in Javanese speech levels. Proceedings of the Fourth Prasasti International Seminar on Linguistics (Prasasti 2018). Solo, Indonesia. pp. 383-387. https://doi. org/10.2991/prasasti-18.2018.70.

Poedjosoedarmo, S. (1968). Javanese speech level. Indonesia Journal, 6, 54-81.

Poedjosoedarmo, S. (2017). Language propriety in Javanese. Journal of Language and Literature, 17(1), 1-9. https://doi.org/10.24071/joll.v17i1.579.

Pohan, F. R. (2020). Javanese language attitude towards speech levels of vernacular in district of Bandar Selamat Medan. Musamus Journal of Language and Literature, 2(2), 56-70. https://doi.org/10.35724/ mujolali.v\%vi\%i.2647.

Pranowo, P. (2015). Unsur intralingual dan ekstralingual sebagai penanda daya bahasa dan nilai rasa bahasa dalam kesantunan berkomunikasi. Adabiyyāt: Jurnal Bahasa Dan Sastra, 14(2), 191-225. https://doi. org/10.14421/ajbs.2015.14202.

Pranowo, P. (2019). Javanese perspective of nonverbal language: An ethnopragmatic study. Lingua Cultura, 13(4), 305-311. https://doi.org/10.21512/ lc.v13i4.6015.

Rahmi, F. U. H. (2018). Kekuasaan, kesantunan, dan solidaritas dalam unggah-ungguh di kalangan santri oleh Ikantan Alumni Futuhiyyah Mranggen Demak. Thaqafiyyat, 19(2), 112-130.

Romelah. (2016). Kekacauan tingkat tutur bahasa Jawa di lingkungan kabupaten Kebumen Jawa Tengah. Lingua, 13(2), 265-276. https://doi.org/10.30957/ lingua.v13i2.181. 
Saddiyah, C., \& Rokhman, F. (2018). Diglossia of JavaneseIndonesia in senior high school educational domain: Sociolinguistics study in Tegal regency. Seloka: Jurnal Pendidikan Bahasa dan Sastra Indonesia, 7(1), 9-17. https://doi.org/10.15294/seloka. v7i1.22621.

Saputri, R. O., Sariono, A., \& Rochiyati, E. (2018). Penggunaan tingkat tutur bahasa Jawa oleh masyarakat etnik Madura di desa Nogosari kecamatan Rambipuji kabupaten Jember. Publikasi Budaya, 6(2), 159-164. https://doi.org/10.19184/ pb.v6i2.8716.

Sudaryanto. (2015). Metode dan aneka teknik analisis bahasa: Pengantar penelitian wahana kebudayaan secara linguistis. Yogyakarta: Sanata Dharma University Press.

Sugianto, R., \& Salehuddin, L. A. R. (2019). The implication of politeness and speech styles in code switching of youth Javanese. Solid ASM Mataram, 9(1), 9-13. https://doi.org/10.35200/solid.v9i1.167.
Sujono, S., Padmaningsih, D., \& Supardjo, S. (2019). A study of Javanese krama speech to the young generation of Java in Surakarta city (Sociolinguistic studies). Proceedings of the Third International Seminar on Recent Language, Literature, and Local Culture Studies. Surakarta, Indonesia. pp. 1-6. https://doi. org/10.4108/eai.20-9-2019.2296899.

Trahutami, S. I. (2016). Pemilihan tingkat tutur bahasa Jawa pada masyarakat desa Klapaduwur Blora. Jurnal "Culture", 3(1), 92-114.

Wahyuningsih, S. (2019). Javanese language shift, gender and modernity: A case study at IAIN Kudus. ELT Lectura, 6(2), 158-169. https://doi.org/10.31849/eltlectura.v6i2.3097.

Winarti, O. (2018). Language shift of krama to bahasa Indonesia among Javanese youths and its relation to parents' social class. Jurnal Studi Komunikasi (Indonesian Journal of Communications Studies), 2(3), 290-300. https://doi.org/10.25139/jsk.v2i3.186.

Zulfikar., Aziz, Z. A., \& Muthalib, K. A. (2020). Language shift by the Javanese in Pulo Loih village, Pidie. English Education Journal (EEJ), 11(2), 215-230. 